\title{
"THE DEAREST BUT THE MOST INFURIATING" HOW TO RAISE A CHILD WITH CHALLENGING TEMPERAMENT?
}

\author{
Mirja Heikkala \\ Satu Uusiautti \\ Kaarina Määttä \\ Faculty of Education, University of Lapland, Finland
}

\begin{abstract}
:
In this research, parents' perceptions of difficult children and their characteristics were studied. A unique point of view to the theme was discovered through the Internet as parenting a challenging child appeared as a theme that is discussed widely in the Internet forums. In these forums, parents write about their experiences voluntarily and at the same time, they are the ones who define their children as challenging or difficult. In this study, parents' descriptions were compared with previous definitions and studies on child temperament. This research was a qualitative research where the interest was in parents' perceptions of difficult children. The data consisted of 118 messages written by 70 different pseudonyms. The messages were analysed through qualitative content analysis. The purpose of the research was to provide further information and tools for parents of children with challenging temperament.
\end{abstract}

Keywords: Temperament; challenging temperament; parenthood.

Corresponding author: Satu Uusiautti

E-mail: satu@uusiautti.fi

Submitted for publication 16/05/2012

Accepted for publication 10/08/2012

Educational Research eJournal ISSN 2254-0385

(C) Faculty of Education. University of Alicante

DOI: 10.5838/erej.2013.21.02 


\section{Introduction}

All of us have a unique temperament or way of reaction and action. Some are faster, others are more careful. These differences come up already in early childhood as every child is one-of-a-kind. Beginning shortly after birth, a child's individuality is manifested in temperament (Thompson, Winer, \& Goodvin, 2011). Every child deserves to grow in an environment that accepts his or her temperament because any temperament is not good or bad as such (Cacciatore, Korteniemi-Poikela, \& Huovinen, 2008). According to Zentner and Bates (2008), despite long history of child temperament research, there is plenty to study of various layers of temperament and the ultimate purpose of all is to enhance children's development. One way in which this can happen is by helping children to overcome temperamentrelated difficulties.

Indeed, some children can be defined as challenging or difficult. Children who are temperamentally highly reactive, difficult to soothe, active, and/or inattentive may be exceedingly difficult for parents to manage (Coplan, Bowker, \& Cooper, 2003). While parenting is not independent of contextual factors (e.g. role satisfaction) or within-the-child characteristics (e.g. temperament); neither are contextual factors or within-the-child characteristics independent of parenting (Heinonen et al., 2002).

\section{Temperament and a Challenging Child}

The New York Longitudinal Study laid the foundation for the individual's unique style of interacting with the environment, in other words, temperament. Thomas et al. (see Chess \& Thomas, 1979; see also Thomasgard, 2003) described nine temperamental traits (activity, intensity, sensitivity, adaptability, approach- withdrawal, persistence, distractibility, rhythmicity, and mood) each ranging from high to low, that work together to determine a child's unique behavioural style. Other child temperament theories are for example Buss and Plomins' behavioural-genetic temperament theory (Buss \& Cantor, 1989) that was later on expanded in adults as well (Strelau, 1998). Furthermore, Thomas's and Chess's clinical tradition was followed by, for example, Kagan, who developed a theory of an inhibited and uninhibited temperament (Kagan, Reznick, \& Cibbons, 1989). The basic idea in this theory is how a child shows inhibition and lack of inhibition to the unfamiliar. Kagan showed that inhibition and shyness has a physiologic background, something that people have as an innate tendency to (Kagan \& Snidman, 2004; see also Keltikangas-Järvinen, 2009b).

Adjustment refers to a human being's ability to adapt to changes, how fast one accepts changes and acts in changing situations and how flexible one can be. Those who have low adaptability find all changes difficult and may reject everything that might unbalance the certain level of stability. For example, a small child tends to start by saying "no" to everything suggested to him or her and the child's adaptability can be easily assessed from the time he or she needs to accept the change. Finally, after accepting the new situation, the child does not want to give up doing it. This may be the very reason why someone is considered difficult. (Keltikangas-Järvinen, 2009a, 96.) According to Keltikangas-Järvinen (2010), human adaptability is not learned but determined by inheritable temperament.

In Finland, the most famous temperament researcher is Prof. Liisa KeltikangasJärvinen. She defines temperament as an aptitude or style that explains the divergence in individuals (see Keltikangas-Järvinen, 2009a). This refers 
to individualistic, gene-based aptitudes for reacting in a certain way both when it comes to the environment and inner states, such as hunger. These aptitudes remain unchangeable across human life-span. Although temperament does not change, a human being does. All experiences have an effect through which one changes either consciously or unconsciously. Despite changes, one's temperament is retained.

Social shyness is manifested as reserve and children are not usually allowed to act like that (Keltikangas-Järvinen, 2010). However, shunning is a good sign of a child's cognitive development because it tells about the child's developed ability to observe, distinguish, and memory development. In addition among infants, it tells that a child has a secure caregiver that he or she is attached to. (Rusanen, 2011). Therefore, temperament is also interpreted in interaction with others (Carey, 1998; Rettew et al., 2006; Rudasill, 2011; Webster-Stratton \& Eyberg, 1982).

Temperamental traits occur as differences in behaviours and ability to concentrate, emotional reactions and motor activity (Strelau, 1998). Temperament does not determine what a person does or why but instead it tells how the person does what he or she does. Neither does temperament reveal anything about the level of one's performance. (Keltikangas-Järvinen, 2009a) The most important outcome of temperament is the personality of an adult human being (Keltikangas-Järvinen, 2009b). Although personality may change, the basic temperament can remain the same. It can be, however, manifested differently at different times. It is noteworthy that a characteristic that gets a baby seem demanding and difficult may appear as determined action by the very same child a few years later. Rearing moulds various temperamental traits in various ways and determines how a child manifests his or her temperament.
(Keltikangas-Järvinen, 2009b.)

However, parents seem to raise children differently according to a child's temperament. A lively child is often rebuked or forbidden and therefore gets plenty of negative attention. Instead, a happy and joyful baby creates a much more positive environment around him or her because others see him or her as an adjusting and pleasing child. (Keltikangas-Järvinen, 2010.) While some temperamental traits are relatively neutral, others are experienced as problematic by other people and these traits are requested to change. A child may develop low self-esteem because he or she is not allowed to act "freely", in his or her natural way (Keltikangas-Järvinen, 2009b). Cacciatore et al. (2008) highlight that everyone has to be accepted as such but some temperamental traits can be controlled when necessary. Each temperamental trait has their strengths and challenges.

There is no unequivocal answer to the question "who is a challenging and difficult child?" While someone can regard his or her child as challenging, some other may find the child easy-going. Therefore, it is worth considering whether there even are difficult children or if is it a matter of inflexible environment. Likewise, Greene (2006) stated that children would behave well if they could. According to Greene, children who have outbursts of rage or behave otherwise inappropriately have been set too high expectations in relation to their cognitive skills. The expectations should not be unreasonably high for anyone but especially not for children who tend to flare up easily. (Greene, 2006). Therefore, the environment should be adjusted to fit better with a child with difficult temperament (Viljamaa, 2008). Challenging children need plenty of mental space and more understanding, encouragement, and love than so-called average children. According to Arnold 
(2010), emotional regulation can be learned best by playing.

A child can also turn difficult if he or she has to face plenty of disappointments. The child experiences hate that he or she tries to express to his or her environment. If no one responds to the child's messages, he or she may keep the negative feelings inside his or her mind. Therefore, each new disappointment can ignite an outburst of rage. (Carey, 1998; Rettew et al., 2006.)

Viljamaa (2008) considers right kind of aggressive behaviour as assertiveness that helps in life whereas KeltikangasJärvinen (2009) disagrees: a human being is fundamentally good. According to her, no one has an innate aptitude for attacking someone but aggression is merely impairment at some phase of mental development. Therefore, challenging or difficult is not equivalent necessarily with aggressive. A difficult temperament may also include irregular biological functions which is not limited in infancy but can continue in adulthood as well (Keltikangas-Järvinen, 2009).

In all, a child with a challenging temperament typically needs time for adjusting and his or her first reaction to new situations is withdrawal, reserve, and avoidance. Departing from routines seems always frightening. Moreover, a child with challenging temperament usually has quite powerful reactions: the child cries often and for a long time, his or her moods are negative, and he or she is often irritable. (Carey, 1998; Keltikangas-Järvinen, 2009c).

When discussing challenging temperament, it is worth highlighting the meaning of positive and negative emotionality as they are significant temperamental characteristics. Namely, emotional experience is thought to be activated by rewarding stimuli and this trait may represent an underlying dimension of sensitivity to signals of incentive reward. Those people who are sensitive for positive emotions possess positive emotionality while negative emotionality is connected to sensitivity for negative emotions. (Depue et al, 1994; see also Kokkonen \& Kinnunen, 2009). Optimism and pessimism are also connected with a child's relationship with parents: according to Heinonen et al.'s (2004) study, dispositional optimismpessimism, dimensions of adult attachment security, and attachmentrelated early childhood recollections are related.

The definition of challenging temperament is difficult to make. According to Carey (1998, p. 525), "parents and teachers are often concerned about certain behaviours that are not abnormal but are only variations of normal temperament traits." Thus, we talk about challenging temperament but not about dysfunction in the child. Indeed, often the problem is just that there exists a poor fit between the temperament and a parent's or teacher's values and expectations (Carey, 1998; see also Rettew et al., 2006). This is where the point in this research is: a parent's perception on a child. Also KeltikangasJärvinen (2009c) pointed out that it is important to realise that a child's temperament is defined challenging based on the fact how much work and trouble it causes to parents and other educators. Therefore, the definition does not focus on the child but merely on others' interpretation of the child.

\section{Method}

\subsection{Research Questions}

In this research, the purpose was to find out what kind of common characteristics children with a challenging temperament have according to parents' opinions and what parents think about raising children with a challenging temperament. Therefore, parents' opinions, perceptions, and experiences are at the core of this 
study.

The research questions set for this study are the following:

1. How do parents describe a child with challenging temperament?

2. How do parents describe being a parent of a child with challenging temperament?

\subsection{Data Collection and Analysis}

This research was a qualitative research where the research theme was carefully chosen (Hirsjärvi et al., 2009). As the interest was in parents' perceptions of difficult children and thus the theme being not only sensitive but also difficult to define, it was challenging to decide the form of data and the actual data collection method. How to recruit parents in this research? How to make sure that they describe their children openly without the researcher's influence? Eventually, internet forums offered open and accessible way of finding parents' descriptions about their children and their own parenting.

The data were collected from the Internet, from a Finnish parenting magazine forum (KaksPlus). In the forum in question, people have animated conversations about children. Internet data were considered suitable in this research because anonymity and obscurity give new kinds of chances to discuss problems (Paunonen, 2004). Especially, ethnomethodologists have spoken for the Internet data because the data type has sprung up in people's everyday life without a researcher's intervention (Denzin \& Lincoln, 2008). Mäkelä (1990) calls data that were born without a researcher's action as natural data and thus, the data in this research can also be seen as natural data. Conversations in the forum resemble talk because the language is usually colloquial language. Therefore, we talk about conversation although it is in a form of written text. Indeed, most of the messages have not been edited for grammar or spelling. In the Internet forum of KaksPlus, people can read others' messages and respond to them via internet (Arpo, 2005). Moderators control conversations and their task is to censor inappropriate messages. In this research, only public forums were used: messages are open to public and accessible to all although there are such forums that require registration as well.

The data collection started by searching conversation with the search word "challenging child". Altogether 2,550 conversations were found. Therefore, it was necessary to decide how to limit the data. The solution was that of these conversation one per year from 2007 to 2012 was chosen. The first message was written in the 5th of November 2007 and the last one in the 9th of January 2012. Messages that concerned children with special needs were excluded because the purpose was not focus on the challenging behaviour of children with a diagnosis.

The data consisted of 118 messages written by 70 different pseudonyms. However, it is not possible to say how many actual people have been writing the messages but the exact number was not relevant in this research. Neither was it possible to know the people's background information: some pseudonyms refer to gender (such as mamma [mommy], muurarin vaimo [brickie's wife], and jokuäiti [somemother]). Yet, when reading between the lines, most writers appeared female. Some of them also contemplated motherhood in their messages. However, it was not possible to interpret gender from every message.

Being a parent of a small, challenging child was topical for all writers but only a few mentioned their age. Neither did the writers reveal their occupation unless they were professional educators and were writing to give advice. Instead, quite many messages included information 
about the child: his or her gender and age. Children's ages varied from infancy to six years. A child's gender was mentioned in 38 messages of which 26 referred to a boy and 12 to a girl. Therefore, it could be interpreted that most of the challenging children in this study were boys.

The data analysis was qualitative categorisation. Tuomi and Sarajärvi (2002) describe content analysis as a tool for analysing documents systematically and objectively. This method aims at drawing a condensed and general description of the phenomenon studied. When analysing texts within content analysis, the focus is on the search of meanings in the text. In practice, the analysis proceeded by diving the simplified expression into main categories. These categories are here introduced as the research results.

We have added some quotes from the data and they include the original pseudonym. If the pseudonym was a clear Finnish word, we have added a translation within square brackets. It also worth noticing that in Finnish language, there are not any separate words for women and men (as there are he and she in English) and therefore, if the author's gender was not recognisable based on the text or pseudonym, we had to use the expression "he/she" when translating the citations from the data.

\section{Results}

\subsection{Characteristics of a Challenging Child}

Based on the data, challenging children are somewhat misfit, quick-tempered, irritable, intensive, highly active, sensitive, and persistent, and have irregular biological functions. Instead, approach and avoidance behaviours or aggression are not uniform in challenging children.

\subsubsection{Low adjustment}

Low adjustment in children with challenging temperament appears as a wish to have everything as is. Even if the change is a pleasant one, children will find it difficult. The following example illustrates how a child can resist a change: "We went, for example, to a picnic in a nice place and the child didn't want to leave. And when we had to leave, he/she shouted. It is already a little bit challenging to drag away a screaming, big child in front of everyone" (Ap, March 22, 2009.)

The pseudonym $A p$ frequently faces similar situations with his/her child. According to the message, $A p$ has to take home the cranky and disappointed child. Parents feel that nothing nice can be done with the child and everything ends with a catastrophe. According to KeltikangasJärvinen (2009a), parents' fast tempo causes trouble for a child with low adjustment. The child just cannot keep up with his/her parents and the stress that follows is unburdened as tantrums or anger. From a child's perspective, adults' action may seem indecisive. But the child only needs more time to adjust.

\subsubsection{Temper}

Many parents described their children as very short-tempered:

"The child is not undisciplined, a complete tyrant, but someone who accelerates from zero to hundred in a second and who doesn't control his/her emotions." (Valaja, March 23, 2009.)

Greene (2006) described these types of children as someone flaring up easily. According to the data, some children enrage dozens of times per day, while others only a few times a week. What is common to these children is, however, that they quickly develop a state that disturbs their doing.

\subsubsection{Testiness}

According to the data, parents reported 
that their children were often in a bad mood. Viljamaa (2009) proved the same: children with challenging temperament are difficult to please. A child is often negative and therefore cranky. In addition, the child typically often cries and for a long time. For example, inimini had experienced these features concretely with his/her child:

"...the child has been yelling for the most of the day and nothing is good..." (inimini, November 20, 2009.)

The abovementioned child has negative emotionality described earlier. The child is sensitive to experiencing negative emotions while positive emotionality means aptitude for experiencing positive emotions. According to the writings in this research, many children had negative emotionality but none of them seemed to have positive emotionality.

\subsubsection{High intensity}

High intensity is manifested in emotional expressions. A child is not embarrassed of announcing his/her feelings aloud. According to Cacciatore, KortenniemiPoikela, and Huovinen (2008), people with high intensity typically express both their good and bad feelings quite powerfully. Many of the messages $(\mathrm{N}=26)$ included a description of a child's behaviour that can be interpreted as high intensity. Moreover, none of the children were described expressing their feelings faintly.

"Everyday life with the child is challenging because all emotions are enormous. If he/she gets mad, sad or happy, the whole world will hear it." (huh! [phew!], March 20, 2010.)

The pseudonym huh! described how a child with high intensity behaves. According to the example, no one will be left uncertain of what the child's feels.

\subsubsection{Irregular biological functions}

In addition to the abovementioned characteristics, a challenging child often suffers from irregular biological functions. Carey (1998) refers to the concept of rhythmicity, which is the regularity of physiologic functions such as hunger, sleep, and defecation. The following example illustrates the everyday life of one family that is challenged by the irregularity in their 10month-old baby's biological functions:

"Still, the baby wakes up about 4-5 times per night and can scream on full blast." (väsynyttt [tireddd], December 16, 2011.) A child with a challenging temperament can often wake up during the night. This can continue for a long time after babyhood. In addition to irregular biological functions, a child with a challenging temperament can suffer from colic (Keltikangas-Järvinen 2009c).

\subsubsection{High activity}

The data also included notions of children's high activity. They were described as energetic and always on the move. This characteristic is not easy relative to the child's environment:

"Everyone just gets exhausted by his/her energy..." (Muurarin vaimo [brickie's wife], March 21, 2010.)

Many parents said that their child's activity was so high that the parents just got tired. An active child was always going somewhere and did nothing peacefully. The activity level is also shown in the child's way of eating, walking, sleeping, etc.

\subsubsection{Sensory threshold}

Some children experience physical contact more unpleasantly than others. Greenspan and Salmon (1996) noted that a challenging child's body simply does not function in a desirable way and therefore can react sensitively to touching or voices. In these data, a child with challenging temperament tended, for example, to resist to clothing or changing situations: "gets nervous in every changing situation, clothing..." (väsynyttt 
[tireddd], December 16, 2011.)

This kind of resistance is easily interpreted as being cranky but actually, clothes may feel unpleasant for the child. None of the parents in this research mentioned sensory threshold but instead they wondering why clothing is always so difficult. This may be because of a child's sensitivity.

\subsubsection{Persistency}

Persistency is one of a challenging child's temperamental traits. A child's environment can find this characteristic challenging because not only do children show persistency in positive situations but also during tantrums. A persistent child can yell and enrage until he or she gets what he or she wants. Persistency is, however, often a sign of assertiveness which is positive as such but may test the parents especially during the child's infancy if the parents do not see the trait as positive.

"...a temperamental and demanding child but I've been thinking that it is a good thing. The child will cope in this world as he/she can hold off [smiley]." (tuu-tikki2, November 14, 2007.)

If parents are able to take a child's persistency well, the trait can become the child's strength later on. As the child's persistency is not suppressed, the child can survive in the challenges of life better.

\subsection{Being a Challenging Child's Parent}

The challenge in rearing refers to the parents' sense of powerlessness as parents. The concept of parenthood stress especially illustrates the stress that a parent experiences when trying to cope with a child (Hyväluoma, Kivijärvi, \& Rönkä, 2009). Although many of the parents said that they were prepared for difficulties when their child was a baby, they had faced more challenges than they had expected. In addition to challenges, many parents had experienced insecurity:
"The problem is that the child does not know how to calm down and we parents don't have any means to help the child to calm down." (Ap, March 22, 2009.)

Regardless of the fact that modern parents are aware of children's needs, they experience more uncertainty about parenthood than before (see Määttä \& Uusiautti, 2011). Parents of a child with challenging temperament may think that they have failed as parents. Most of the parents in the internet forum studied in this research shared their experience of having done something wrong and compared their parenting skills to other parents, especially those who had easy children:

"Somehow I often have the feeling that I have failed in parenting as my baby/toddler just acts up and cries even if I tried everything. Nowadays I don't even try very often... I have also 'failed' when it comes to night time and sleeping: my friends' babies sleep so well and peacefully already at the few-months' age..." (Ninskuliina, July 1, 2008.)

The abovementioned parent tells how tired she is as a parent. She has already given up at certain level and does not have the energy to meet the child's needs as would be necessary. A child constructs his/her self-image in interaction with others, especially with his/her own parents (Rettew et al., 2006). Therefore, the care that a child gets from parents is crucial.

Despite the demands of the everyday life with a challenging child, some parents were able to regard their child calmly and had not become tired of the situation. A child's temperament can turn into the child's strengths. The way a parent responds to a child's temperament depends on the parent's own temperament, life experiences, points of interest, and expectations toward the child (Brooks \& Goldstein, 2002). The following example illustrates a parent who views her challenging child positively: "Luckily, I 
remember to think about that this little human being will manage and will not lose out to others." (Annastiina 1977, November 12, 2007.)

A few parents in this data knew how to turn challenging temperament into a child's strength. This kind of attitude can have a very positive influence on the child's future. Although the child behaved in a challenging way, parents did not have the feeling of doing or being wrong. Therefore, children of these parents can have the opportunity to develop good self-esteem.

\section{Discussion}

Based on the research, gender and challenging temperament in children seemed to be interconnected because most of the children whose gender was mentioned were boys $(\mathrm{N}=26)$. Also Crockenberg (2003) found out that especially boys are proved to express more negative emotions than girls. Thus, the summary of this research is the following: Generally, a challenging child is a boy who has high intensity - in other words, tends to express his emotions loudly. He has low adaptability and therefore all changes may seem difficult for him. Due to this trait, a challenging child often resists daily routines such as eating or changing. If he could choose, everything would stay as before. A child with challenging temperament has negative emotionality that appears as testiness. A challenging child is also lively but not particularly aggressive. Typically, a challenging child resists clothing which can be connected to high amount of sensory stimulation. In addition, irregular biological functions are typical of challenging temperament: during infancy, a challenging child may suffer from colic and wakes up several times per night also after babyhood. A challenging child can represent either approach or withdrawal by the nature of his responses to new stimuli. In addition, a child with challenging temperament can be persistent but, on the other hand, the ability to tolerate failures can be weak. Sudden flusters are typical of shorttempered character. (see also Carey, 1998; Coplan, Bowker, \& Cooper, 2003; see also Thompson, Winer, \& Goodvin, 2011).

Most of the parents described how raising a challenging child tested their parenthood. They believed that the challenging behaviour was connected to their own behaviour as parents and therefore started to think that they had failed as parents. They experienced powerlessness, despair, and fatigue. The parenthood stress was especially increased by a child's testiness that the parents could not change regardless of all attempts. This added their frustration and some parents had stopped trying. Many parents had tried "penalty boxes" and various rewards to change a child's behaviour with no success. Some parents had realised that their child had a challenging temperament but not all. Some of them thought that their child just acts up for the fun of it or to tease the parents. In all, the parents who were aware of challenging temperament formed a minority in this data. These parents were able to treat their children more compassionately and understood the children better. They believed that the challenging temperament would eventually become a strength that appears as positive assertiveness and persistency.

\section{Conclusions}

Nowadays, modern parenthood is evaluated from the point of view of children's well-being and balanced development. Yet, good parenthood cannot be defined unambiguously as there is no model that would fit to all parents. Bruno Bettelheim (1980) created a concept of "good enough parents" that refers to parenthood where it is enough if 
parents are themselves and act consistently according to their values. No one can be a perfect parent and it is not worthwhile to even try to reach for it.

However, parenthood includes challenges and in the middle of daily busyness parents cannot always act as they would have wanted to. Perhaps, the idea of "good enough parents" could be complemented with the idea of pedagogical love (see Määttä \& Uusiautti, 2011; 2012) and raising children toward goodness (Uusiautti \& Määttä, 2012a; 2012b). Storh (2009, p. 136) states that "[m]y flourishing depends on the flourishing of others." Transmitting this kind of an attitude in children could be the main guideline in upbringing. This is what love fundamentally is, and children will learn to use it if we-as educators, parents, and other significant people in children's life - set an example by directing our mindful and loving action in children and other people as well. (see also Määttä \& Uusiautti, 2011, 2012; Uusiautti \& Määttä, 2011). Children's well-being thus is the responsibility of those people who live with and live close to children (Ambert, 1994; Arendell, 1997) and parents have the key role.

Challenging children may seem difficult to raise but the purpose of this study was to show that the challenging temperament is not a child's fault but a feature that can be turned as a strength. Parents of children with challenging temperament can easily feel guilt because they cannot always act as model parents or by the book. Therefore, the second purpose of this article was also to provide parents with information about challenging children and show that they are not alone but the situation is similar in many families. Realising that challenging temperament can be the reason for a child's demands can help parents take their child in a more empathetic, accepting, and loving way.

Indeed, Crockenberg (2003, p. 1036) pointed out that "it should come as no surprise that caring all day for young children who get upset easily and recover slowly could be wearing, even for loving parents." Therefore, along with understanding that caring for reactive children can be draining, to be happy about life, to guide children to see the wonder and joy in the mundane is a parent's important skill. Learning the joy of life can be crucial for many children with challenging temperament in order to avoid or survive the darker depths of life. (See Määttä \& Uusiautti, 2011.) Having experienced acceptance and love, even the most challenging and difficult temperament has the chance to turn into a child's strength that will help him or her to do well in life.

\section{References}

Arnold \& the Pen Green Team. (2010). Understanding schemas and emotion in early childhood. U.K.: MPG Books Group. [Abstract] [Back to text]

Arpo, R. (2005). Internetin keskustelukulttuurit. Tutkimus internet-keskusteluryhmien viesteissä rakentuvista puhetavoista, tulkinnoista ja tulkinnan kehyksistä kommunikaatioyhteiskunnassa [Conversation cultures of the internet. A study of manners of speaking, interpretations, and framework of interpretation in the communication society that are constructed in the messages of internet forums]. Joensuu: University of Joensuu. [Full text] [Back to text]

Buss, D. \& Cantor, N. (1989). Personality psychology. Recent trends and emerging directions. 
Harrisonburg: R.R Donnelley \&

Sons. [Abstract] [Back to text]

Cacciatore, R., Korteniemi-Poikela, E. \& Huovinen, M. (2008). Miten tuen lapsen ja nuoren itsetuntoa [How to support a child's and youngster's self-esteem]. Juva: WS Bookwell. [Back to text]

Carey, W. B. (1998). Temperament and behavior problems in the classroom. School Psychology Review, 27(4), 522-533. [Full text] [Back to text]

Coplan, R. J., Bowker, A. \& Cooper, S. M. (2003). Parenting daily hassles, child temperament, and social adjustment in preschool. Early Childhood Research Quarterly, 18, 376395.doi:10.1016/S08852006(03)00045-0 [Full text] [Back to text]

Crockenberg, S. C. (2003). Rescuing the baby from the bathwater: How gender and temperament (may) influence, how child care affects child development. Child Development, 74(4), 1034-1038. [Full text] [Back to text]

Denzin, N. K. \& Lincoln, Y. S. (2008). Introduction: The discipline and practice of qualitative research. In N. K. Denzin \& Y.S. Lincoln (Eds.), Handbook of qualitative research (pp. 1-29), Thousand Oaks, CA: SAGE. [Full text] [Back to text]

Depue, R. A., Luciana, M., Arbisi, P., Collins, P. \& Leon, A. (1994). Dopamine and the structure of personality: relation of agonistinduced dopamine activity to positive emotionality. Journal of Personality and Social
Psychology, 67(3), 485-498.

[Abstract] [Back to text]

Greene, R. W. (2006). Tulistuva lapsi. Uusi lähestymistapa helposti turhautuvien ja joustamattomien lasten ymmärtämiseen ja tukemiseen [A short-tempered child. A new approach to the understanding and support of easily frustrated and inflexible children]. Keuruu: Otava. [Back to text]

Heinonen, K., Räikkönen, K., Keskivaara, P. \& KeltikangasJärvinen, L. (2002). Difficult temperament predicts self-esteem in adolescence. European Journal of Personality, 16(6), 439-455. doi: 10.1002/per.464 [Full text] [Back to text]

Heinonen, K., Räikkönen, K., Keltikangas-Järvinen, L. \& Strandberg, T. (2004). Adult attachment dimensions and recollections of childhood family context: associations with dispositional optimism and pessimism. European Journal of Personality, 18(3), 193-207. doi: 10.1002/per.508

[Full text] [Back to text]

Chess, S. \& Thomas, A. (1979). Annual progress in child psychiatry and child development. New York, NY: Brunner/Mazel. [Back to text]

Hirsjärvi, S., Remes, P. \& Sajavaara, P. (2009). Tutki ja kirjoita [Research and write]. (15th ed.) Hämeenlinna: Kariston kirjapaino. [Back to text]

Hyväluoma, J., kivijärvi, S. \& Rönkä, A. (2009). Vanhemmuus arjessa: neuvottelua, hässäköitä ja hassuttelua [Parenthood in everyday life: negotiation, fuss, and 
whimsy]. In A. Rönkä, K. Malinen \& T. Lämsä (Eds.), Perhe-elämän paletti. Vanhempana ja puolisona vaihtelevassa arjessa [The palette of family life. Being a parent and a spouse in ever-changing everyday life] (pp. 47-68). Juva: WS Bookwell. [Back to text]

Kagan, J., Reznick, J. S. \& Cibbons, J. (1989). Inhibited and uninhibited types of children. Child Development, 60, 838845. [Abstract] [Back to text]

Kagan, J. \& Snidman, N. (2004). Long shadow of temperament. Cambridge, MA: Harvard University Press.

[Abstract] [Back to text]

Keltikangas-Järvinen, L. (2009a). Temperamentti, stressi ja elämänhallinta [Temperament, stress, and life management]. Juva: WS Bookwell. [Abstract] [Back to text]

Keltikangas-Järvinen, L. (2009b). Temperamentti - persoonallisuuden biologinen selkäranka [Temperament - the biological backbone of personality]. In R-L. Metsäpelto \& T. Feldt (Eds.), Meitä on moneksi. Persoonallisuuden psykologiset perusteet [We are different. Psychological foundation of personality] (pp. 49-70). Juva: WS Bookwell. [Back to text]

Keltikangas-Järvinen, L. (2009c). Temperamentti - ihmisen yksilöllisyys [Temperament human individuality]. Juva: WS Bookwell. [Back to text]

Keltikangas-Järvinen, L. (2010). Sosiaalisuus ja sosiaaliset taidot [Sociality and social skills]. Juva: WS Bookwell. [Abstract] [Back to text]
Kokkonen, M. \& Kinnunen, M.-L. (2009). Tunteiden säätelyssä persoonallisuus pelissä [Personality has a role in emotional regulation]. In R-L. Metsäpelto \& T. Feldt (Eds.), Meitä on moneksi. Persoonallisuuden psykologiset perusteet [We are different. Psychological foundation of personality] (pp. 145-158). Juva: WS Bookwell. [Back to text]

Mäkelä, K. (1990). Kvalitatiivisen analyysin arviointiperusteet [Basics of evaluating qualitative analysis]. In K. Mäkelä (Ed.), Kvalitatiivisen aineiston analyysi ja tulkinta [Analysis and interpretation of qualitative data] (pp. 42-61). Helsinki: Painokaari Oy. [Back to text]

Määttä, K. \& Uusiautti, S. (2011). Pedagogical love and good teacherhood. In Education, 17(2). [Full text] [Back to text]

Määttä, K. \& Uusiautti, S. (2012). Pedagogical authority and pedagogical love - connected or incompatible? International Journal of Whole Schooling, 8(1), 21-39.

[Full text] [Back to text]

Paunonen, U. (2004). <Seireeni> *huokaus*, Missä Mr. Cool? Tapaustutkimus aikuisten virtuaalisista seurusteluyhteisöistä $[<$ Seiren $>$ *sigh*, Where's Mr. Cool? A case study on adults' virtual dating communities]. In U. Paunonen \& J. Suominen (Eds.), Digirakkaus [Digital love] (pp. 35-43). Tampere: Tammer-Paino. [Back to text] 
Rettew, D. C., Stanger, C., McKee, L., Doyle, A. \& Hudziak, J. J. (2006). Interactions between child and parent temperament and child behavior problems. Comprehensive Psychiatry, 47, 412-420.doi:

10.1016/j.comppsych.2005.12.00

8 [Full text] [Back to text]

Rudasill, K. M. (2011). Child temperament, teacher-child interactions, and teacher-child relationships: A longitudinal investigation from first to third grade. Early Childhood Research Quarterly, 26, 147-16. doi: 10.1016/j.ecresq.2010.07.002 [Full text] [Back to text]

Rusanen, E. (2011). Hoiva, kiintymys ja lapsen kehitys [Care, attachment, and child development]. Porvoo: Bookwell. [Back to text]

Storh, K. (2009). Minding others' business. Pacific Philosophical Quarterly, 90, 116-139. [Full text] [Back to text]

Strelau, J. (1998). Temperament: A psychological perspective. Hingham, MA: Kluwer Academic.

[Abstract] [Back to text]

Thomasgard, M. (2003). Working with challenging young children: relations between child temperament, response to novelty and sensory processing. Clinical Pediatrics, 42(3), 197-204. doi: 10.1177/000992280304200302 [Full text] [Back to text]

Thompson, R. A., Winer, A. C. \& Goodvin, R. (2011). The individual child: temperament, emotion, self and personality. In M. E. Lamb \& M. H. Bornstein (Eds.), Social and personality development (pp.217-258). New York, NY: PsyPress. [Full text] [Back to text]

Tuomi, J. \& Sarajärvi, A. (2002). Laadullinen tutkimus ja sisällönanalyysi [Qualitative research and content analysis]. Jyväskylä: Gummerus. [Back to text]

Uusiautti, S. \& Määttä, K. (2011). The ability to love - a virtue-based approach. British Journal of Educational Research, 2(1), 1-19. [Full text] [Back to text]

Uusiautti, S. \& Määttä, K. (2012a). How to employ love-based leadership at school? Journal of Social Sciences, in press, 2(3), 260-270. [Back to text]

Uusiautti, S. \& Määttä, K. (2012b). Can teachers teach children how to be moral? British Journal of Education, Society \& Behavioural Science, in press. [Back to text]

Viljamaa, J. (2008). Anna lapsen onnistua [Let the child succeed]. Jyväskylä: Gummerus. [Back to text]

Webster-Stratton, C. \& Eyberg, S.M. (1982). Child temperament: relationship with child behavior problems and parent-child interactions. Journal of Clinical Child Psychology, 11(2), 123129. [Abstract] [Back to text]

Zentner, M. \& Bates, J. E. (2008). Child temperament: An integrative review of concepts, research programs, and measures. European Journal of Developmental Science, 2(1/2), 7-37. [Abstract] [Back to text] 